\title{
Kepemimpinan Visioner Kepala Sekolah Terhadap Mutu dan Kualitas Sekolah di SD Negeri Soko
}

\author{
Rati Purwanto*1 \\ ${ }^{1}$ Sekolah Dasar Negeri Soko, Lamongan, Jawa Timur, Indonesia \\ Email: ${ }^{1}$ ratipurwanto1971@gmail.com
}

\begin{abstract}
Abstrak
Maju atau mundurnya sebuah institusi ditentukan oleh gaya kepemimpinan, demikian pula di lembaga pendidikan seperti sekolah, sekolah akan mengalami kemajuan yang pesat apabila pemimpinnya mempunyai gaya kepemimpinan yang tepat. Salah satu gaya kepemimpinan untuk meningkatkan mutu dan kualitas adalah gaya kepemimpinan visioner. Meningkatkan mutu dan kualitas pendidikan dalam lembaga persekolahan sangatlah sulit jika tidak diiringi dengan peningkatan kinerja guru. Hal ini disebabkan karena guru merupakan komponen yang paling menentukan dalam sistem pendidikan secara keseluruhan yang harus mendapatkan perhatian sentral. Kepemimpinan visioner ini dapat memberikan pengaruh yang signifikan terhadap peningkatan kinerja guru karena kepala sekolah dapat memberikan visi yang jelas dan dapat mengimplementasikan visi yang telah dibuatnya untuk masa depan guru tersebut, sehingga dengan peningkatan kinerja guru diharapkan terjadi peningkatan pula terhadap mutu dan kualitas pendidikan di SD Negeri Soko. Best practice ini, kepemimpinan visioner kepala sekolah memiliki sub variabel : Fokus pada tujuan organisasi; Membuat rencana jangka panjang; Mengembangkan Visi Bagi Masa Depan Organisasi; Selalu Berada dalam Kondisi Siap dan Dinamis untuk Perubahan; dan Selalu Mengetahui Perubahan Kebutuhan Konstituen. Kepemimpinan visioner kepala sekolah dan kinerja mengajar guru berpengaruh secara positif dan signifikan terhadap efektivitas sekolah pada Sekolah Dasar Negeri. Hal ini mengindikasikan efektivitas sekolah ditentukan oleh kepemimpinan visioner kepala sekolah dan kinerja mengajar guru secara bersama-sama. Semakin baik kepemimpinan visioner kepala sekolah dan kinerja mengajar guru maka efektivitas sekolah akan semakin baik dan mengalami peningkatan.
\end{abstract}

Kata kunci: kinerja guru, kepemimpinan visioner, kualitas sekolah, mutu

\section{Principal's Visionary Leadership on School Quality at SD Negeri Soko}

\begin{abstract}
The progress or withdrawal of an institution is determined by the leadership style, likewise in educational institutions such as schools, schools will experience rapid progress if the leader has the right leadership style. One of the leadership styles to improve quality and quality is a visionary leadership style. Improving the quality and quality of education in schooling institutions is very difficult if it is not accompanied by an increase in teacher performance. This is because the teacher is the most decisive component in the education system as a whole which must receive central attention. This visionary leadership can have a significant effect on improving teacher performance because the principal can provide a clear vision and can implement the vision he has made for the future of the teacher, so that with an increase in teacher performance it is expected that there will also be an increase in the quality and quality of education in SD Negeri Soko. This best practice, the principal's visionary leadership has sub variables: Focus on organizational goals; Make long term plans; Developing a Vision for the Future of the Organization; Always Be Ready and Dynamic for Change; and Always Know the Changing Needs of Constituents. Principal's visionary leadership and teacher teaching performance have a positive and significant effect on school effectiveness at public elementary schools. This indicates that school effectiveness is determined by the visionary leadership of the principal and the teaching performance of teachers together. The better the visionary leadership of the principal and the teaching performance of the teacher, the better and the increase in school effectiveness.
\end{abstract}

Keywords: quality, school quality, teacher performance, visionary leadership. 


\section{PENDAHULUAN}

Maju atau mundurnya sebuah institusi ditentukan oleh gaya kepemimpinan, demikian pula di lembaga pendidikan seperti sekolah, sekolah akan mengalami kemajuan yang pesat apabila sekolah pemimpinnya mempunyai gaya kepemimpinan yang tepat, salah satu gaya kepemimpinan untuk meningkatkan mutu dan kualitas adalah gaya kepemimpinan visioner. Gaya kepemimpinan visioner adalah kemampuan pemimpin dalam mencipta, merumuskan, mengkomunikasikan, mensosialisasikan, mentranformasikan dan mengimplementasikan pemikiran-pemikiran ideal yang berasal dari dirinya atau sebagai hasil interaksi sosial antar anggota dan stakeholder yang sebagai sebuah cita-cita organisasi di masa depan yang harus diraih secara bersama-sama.

Kinerja guru (teacher performance) merupakan hasil kerja atau unjuk kerja atas segala kegiatan saat mengajar yang dilakukan sesuai dengan petunjuk atau pedoman yang telah ditetapkan. Gambaran kinerja guru dalam best practice ini difokuskan pada kinerja mengajar dalam menyusun perencanaan pembelajaran,

melaksanakan kegiatan pembelajaran dan serta melaksanakan evaluasi pembelajaran.

Perencanaan pembelajaran merupakan kunci pelaksanaan pola pembelajaran yang berkualitas. Untuk melaksanakan unjuk kerja guru dalam konteks kinerja, maka pelaksanaan proses pembelajaran harus didukung dengan sarana dan prasarana pendidikan yang memadai, sesuai dengan kebutuhan materi pembelajaran yang hendak disampaikan. Kinerja guru dalam konteks pembelajaran dibuktikan dengan segala kemampuan guru dalam menyusun program pengajaran, program pembelajaran yang dimaksud, merencanakan pembelajaran yang diawali dengan menyusun berbagai persiapan dintaranya melakukan kajian analisis dan pemetaan terhadap kompetensi dasar, menjabarkan kompetensi dasar menjadi butir-butir indikator pencapaian, merumuskan tujuan pembelajaran, menentukan kriteria ketuntasan minimal, menyiapkan materi pembelajaran, memilih metode serta model pembelajaran yang sesuai, merencanakan langkah-langkah dalam kegiatan belajar mengajar, mengkondisikan siswa, melakukan apersepsi, memotivasi siswa, melakukan studi eksplorasi, elaborasi dan konfirmasi, yang pada akhirnya melakukan rencana pembelajaran, melaksanakan pembelajaran dan mempersiapkan instrumen untuk menilai hasil belajar.

Guru dengan layanan kinerja mengajar yang prima, dengan berbagai tahapan dan persiapan yang dilakukan dalam melaksanakan tugas mengajar dapat membangun kepercayaan publik sehingga berdampak dalam mewujudkan mutu dan kualitas sekolah sebagaimana yang diharapkan.

SD Negeri Soko adalah salah satu sekolah dasar negeri di wilayah kecamatan Glagah. Sekolah yang berdiri pada tahun 1963 ini mempunyai segudang prestasi, di sisi lain perkembangan dari segi kuantitas begitu nyata terlihat. Sementara dari segi mutu dan kualitas, SD Negeri Soko berusaha terus membenahi hingga seluruh harapan bisa tercapai. Salah satu variabel penentu peningkatan mutu dan kualitas sekolah adalah gaya kepemimpinan visioner kepala sekolah dan kinerja baik dari para dewa gurunya. Sekolah dasar yang mempunyai visi "Terciptanya Manusia Yang Beriman dan Taqwa Cerdas, Terampil Serta Berbudi Pekerti Luhur" ini menerapkan pembelajaran 6 hari efektif dengan menggunakan kurikulum 2013. Dengan gaya kepemimpinan visioner dan kinerja guru yang baik SD Negeri Soko mampu menjadi sekolah dasar yang penuh prestasi dan berkarakter, fenomena ini menjadi suatu kajian yang menarik untuk dijadikan kajian penelitian di tengah-tengah sekolah dasar negeri yang mulai menurun mutu dan kualitasnya.

Kepemimpinan kepala sekolah yang relevan dengan tuntutan manajemen berbasis sekolah "school based management" dan didambakan bagi produktivitas Pendidikan adalah kepemimpinan yang memiliki visi (visionary leadership) yaitu kepemimpinan yang kerja pokoknya difokuskan pada rekayasa masa depan yang penuh tantangan, menjadi agen perubahan (agent of change) yang unggul dan menjadi penentu arah organisasi yang tahu prioritas, menjadi pelatih yang profesional dan dapat membimbing personil lainnya ke arah profesionalisme kerja yang diharapkan.

Salah satu syarat kepemimpinan di era otonomi adalah pemimpin visioner, dimana organisasi harus menampilkan kekuatan dan ciri khas budayanya menuju kualitas pendidikan yang diharapkan. Visi tercipta dari kreativitas pikir pemimpin sebagai refleksi profesionalisme dan pengalaman pribadi atau sebagai hasil elaborasi pemikiran mendalam dengan pengikut (personel lain), yaitu berupa ide-ide ideal tentang cita-cita organisasi di masa depan yang ingin diwujudkan bersama.

Buku [1] mendefinisikan visi sebagai berikut: "Vision defines the ideal future, perhaps implying retention of the current culture and the activities, or perhaps implying change". Artnya, visi menggambarkan masa depan yang ideal, menyiratkan ingatan budaya yang sekarang dan aktivitas, atau menyiratkan perubahan. Terbentuknya visi dipengaruhi oleh pengalaman hidup, pendidikan, pengalaman profesional, interaksi dan komunikasi, penemuan keilmuan serta kegiatan intelektual yang membentuk pola pikir (mindset) tertentu[2].

Seorang pemimpin yang mempunyai konsep tentang: (1) bagaimana merekayasa masa depan untuk menciptakan Pendidikan yang produktif; (2) menjadikan dirinya sebagai agen perubahan; (3) memposisikan sebagai penentu arah organisasi; (4) pelatih atau pembimbing yang profesional; (5) mampu menampilkan kekuatan pengetahuan berdasarkan pengalaman profesional dan pendidikannya, dengan didukung oleh ciri khas 
budaya kerja dalam mencapai tujuan yang ditetapkan dalam visi dan dijabarkan dalam misi, dapat dikatakan sebagai kepemimpinan yang visioner.

Mutu dan kualitas SD Negeri Soko dipengaruhi oleh kepemimpinan kepala sekolah yang visioner dalam melaksanakan tugas dan tanggung jawabnya. Salah satu cermin peningkatan mutu pendidikan di sekolah adalah kemampuan kepala sekolah yang visioner dalam mengelola sekolah sesuai dengan visi, misi, tujuan dan sasaran yang akan dicapai.

Kepala sekolah yang visioner di SD Negeri Soko harus dapat mengemban tanggung jawabnya memimpin sekolah dengan berhasil. Kepala sekolah yang visioner harus tahu persis visi dan misi apa yang ingin dicapai dan bagaimana mewujudkan visi dan misi tersebut dalam sebuah amanah yang diemban. Kepala sekolah yang visioner di SD Negeri Soko harus memahami betapa pentingnya mengajak semua pihak terkait dalam sekolahnya untuk bersama-sama mewujudkan visi yang telah dirumuskan bersama. Implikasi sifat visioner, kepala sekolah harus memiliki sejumlah kompetensi dan integritas untuk melaksanakan misi guna mewujudkan visi itu, dan selanjutnya kepala sekolah juga harus memiliki sejumlah karakter tertentu yang menunjukkan integritasnya.

Sebuah lembaga atau sekolah tentunya memiliki sebuah visi yang dibuat oleh kepala sekolah, visi ini sebagai rencana awal yang memiliki tujuan jangka panjang untuk kesuksesan sebuah lembaga. Kepemimpinan visioner adalah kemampuan pemimpin untuk menciptakan dan mengartikulasikan suatu visi yang realistik, dapat dipercaya, atraktif tentang masa depan bagi suatu organisasi atau unit organisasional yang terus bertumbuh dan meningkat sampai saat ini[3].

Kepemimpinan yang bervisi bekerja dalam 4 (empat) pilar sebagaimana dikatakan [4] dalam [5] yaitu kemampuan dalam menentukan arah, memahami keinginan masyarakat atau konsumen, berpengaruh dalam aktivitas dan menjadi pemandu, dan mampu mengantisipasi masa depan/sebagai agen perubahan.

Sesuai dengan indikator dalam kepemimpinan visioner di atas, diharapkan kepala sekolah mampu mendorong para guru agar senantiasa meningkatkan kinerjanya dalam kerangka visi yang telah dibuat. Komuniksi yang terjalin dengan baik selalu diupayakan agar terjadi sharing untuk meningkatkan mutu sekolah. Kepala sekolah sebagai pimpinan dituntut mampu merencanakan program untuk keberlangsungan sekolah. Baik rencana yang bersifat jangka pendek maupun jangka panjang. Perkembangan zaman yang terus terjadi merupakan tantangan yang harus dihadapi dengan baik. Paper [6] mengemukakan keberhasilan sekolah dalam meningkatkan mutu pendidikannya, baik mutu akademik maupun non akademik sangat tergantung pada kepala sekolah untuk memimpin dengan visi. Perannya sebagai pemimpin visioner dapat meningkatkan mutu sekolah, salah satunya dengan peningkatan kualitas guru. Namun jika kepala sekolah tidak mempunyai visi ke depan maka akan menghambat perkembangan kreativitas guru. Dalam proses mengajar, guru hanya mengajar sesuai dengan tugasnya saja dalam mengajar, mereka tidak mempunyai target yang jelas sebagai hasil dari proses pembelajaran tersebut.

Sejalan dengan pernyataan tersebut, kepala sekolah yang visioner menjadi variabel penting dalam penelitian ini untuk mewujudkan pendidikan yang bermutu di SD Negeri Soko. Hal ini disebabkan karena kepemimpinan kepala sekolah yang visioner merupakan komponen yang penting yang dapat meningkatkan kualitas persekolahan melalui fungsi dan perannya. Oleh karena itu diperlukan kepala sekolah yang berkualitas, memiliki visi dan misi, memiliki kompetensi dan integritas yang tinggi.

Meningkatkan mutu dan kualitas pendidikan dalam lembaga persekolahan sangatlah sulit jika tidak diiringi dengan peningkatan kinerja guru. Hal ini disebabkan karena guru merupakan komponen yang paling menentukan dalam sistem pendidikan secara keseluruhan yang harus mendapatkan perhatian sentral. Karena guru memegang peranan utama dalam pembangunan pendidikan, khususnya yang diselenggarakan secara formal di sekolah. Dalam proses pendidikan di sekolah, guru memegang tugas ganda yaitu sebagai pengajar dan pendidik.

Sebagai pengajar guru bertugas memberikan sejumlah bahan pelajaran kepada peserta didik, sedangkan sebagai pendidik guru bertugas membimbing dan membina peserta didik agar menjadi manusia yang cakap, aktif, kreatif, dan mandiri.

Kinerja guru merupakan sarana penentu dalam mencapai tujuan sekolah, baik tujuan pendidikan nasional maupun tujuan institusional sehingga perlu diupayakan untuk meningkatkan kinerjanya. Namun hal ini tidak mudah dilakukan, sebab banyak faktor yang mempengaruhi tinggi rendahnya kinerja guru.

Faktor rendahnya kinerja guru menurut hasil penelitian [7] antara lain disebabkan oleh motivasi kerja, tidak punya etos kerja yang tinggi, dan tidak produktif, yang antara lain tampak dari gejala-gejala berikut ini: (1) Lemahnya penguasaan bahan yang diajarkan; (2) Ketidaksesuaian antara bidang studi yang dipelajari guru dan yang dalam kenyataan lapangan yang diajarkan; (3) Kurang efektifnya cara pengajaran; (4) Kurangnya wibawa guru dihadapan murid; (5) Lemahnya motivasi dan dedikasi untuk menjadi pendidik yang sungguh-sungguh, semakin banyak yang kebetulan menjadi guru dan tidak betul-betul menjadi guru; (6) Kurangnya kematangan emosional, kemandirian berpikir, dan keteguhan sikap dalam cukup banyak guru sehingga dari kepribadian 
mereka sebenarnya tidak siap sebagai pendidik; dan (7) Kebanyakan guru dalam hubungan dengan murid masih hanya berfungsi sebagai pengajar dan belum sebagai pendidik.

Adanya masalah-masalah tersebut di atas, menunjukkan bahwa kinerja guru harus ditingkatkan menjadi lebih baik dan salah satu faktor yang dapat meningkatkan kinerja guru adalah kepemimpinan kepala sekolah, diantaranya model kepemimpinan kepala sekolah ialah kepemimpinan visioner. Hal ini sebagaimana ditegaskan [8] bahwa kepemimpinan begitu kuat mempengaruhi kinerja organisasi sehingga rasional. Visi dapat mengisi kehampaan, membangkitkan semangat, menimbulkan kinerja, bahkan mewujudkan prestasi pendidikan. Sebuah visi pada lembaga pendidikan atau sekolah tidaklah hanya sebagai simbol-simbol saja melainkan harus diimplementasikan oleh kepala sekolah karena dengan diimplementasikan dapat meningkatkan kinerja guru di SD Negeri Soko.

Kepemimpinan visioner ini dapat memberikan pengaruh yang signifikan terhadap peningkatan kinerja guru karena kepala sekolah dapat memberikan visi yang jelas dan dapat mengimplementasikan visi yang telah dibuatnya untuk masa depan guru tersebut, sehingga dengan peningkatan kinerja guru diharapkan terjadi peningkatan pula terhadap mutu dan kualitas Pendidikan di SD Negeri Soko.

\section{KAJIAN PUSTAKA}

\subsection{Kepemimpinan Visioner}

Menurut [4], "pemimpin visioner memiliki empat peran yang harus dijalankan dalam melaksanakan kepemimpinannya". Yaitu : Pertama, peran penentu arah (direction setter). Peran ini merupakan peran di mana seorang pemimpin menyajikan suatu visi, meyakinkan target untuk suatu organisasi, guna diraih pada masa depan, dan melibatkan orang-orang. Kedua, agen perubahan (agent of change). Agen perubahan merupakan peran penting kedua dari seorang pemimpin visioner. Ketiga, juru bicara (spokesperson). Memperoleh pesan ke luar, dan juga berbicara, boleh dikatakan merupakan suatu bagian penting dari memimpikan masa depan suatu organisasi. Keempat, pelatih (coach). Pemimpin visioner yang efektif harus menjadi pelatih yang baik. Dengan ini berarti bahwa seorang pemimpin harus menggunakan kerjasama kelompok untuk mencapai visi yang dinyatakan juga berbicara, boleh dikatakan merupakan suatu bagian penting dari memimpikan masa depan suatu organisasi.. Keempat, pelatih (coach). Pemimpin visioner yang efektif harus menjadi pelatih yang baik. Dengan ini berarti bahwa seorang pemimpin harus menggunakan kerjasama kelompok untuk mencapai visi yang dinyatakan.

Masih menurut [4], para pemimpin yang efektif selalu mempunyai rencana, berorientasi pada hasil, senantiasa mengadopsi visi-visi baru yang menantang tetapi bisa dijangaku, mengkomunikasikannya visi-visi tersebut kepada seluruh anggotanya. Visi yang kuat akan menuntun menuju kepemimpinan yang sukses, karena kepemimpinan yang sukses merupakan kunci keberhasilan organisasi. Organisasi yang sukses adalah organisasi yang mampu melahirkan pemimpin-pemimpin dengan komitmen kuat, memiliki visi masa depan, dan mampu mengkoordinasikan seluruh anggotanya.

Merujuk pada konsep kepemimpinan kepala sekolah yang ada yang sangat dibutuhkan dan urgen pada saat ini dalam menjawab semua perubahan dan tantangan yang ada dalam menciptakan dan membangun keefektifan sekolah di sekolah Dasar adalah kepemimpinan visioner kepala sekolah. Mengapa? visioner adalah orang yang memiliki wawasan ke depan[9].

Visioner juga mengkontruksi perubahan-perubahan yang dinamis, lebih memikirkan pada manfaat, nilai dan tanggung jawab. Visioner menunjukkan sifatnya terbuka dan melihat pada potensi- potensi yang mungkin terjadi tanpa mempunyai kepastian mengenai hasil- hasilnya. Masa depan adalah masa kini yang sedang diarahkan oleh manusia itu sendiri. Visi masa depan ini harus dimiliki oleh setiap pemimpin sekolah.

Dari beberapa pendapat ahli tentang kepemimpinan peneliti menyimpulkan menyimpulkan bahwa yang dimaksud kepemimpinan dalam pendidikan adalah segala tindakan, dan perbuatanyang dilakukan oleh seseorang atau kelompok dalam suatu wadah tertentu yang memberikan pengaruh, bimbingan, arahan, keinginan, tujuan, mengkoordinasikan, inisiatif, perintah, hubungan sosial, menentukan prosedur, merancang perbuatan dalam rangka mencapai tujuan yang menjadi kesepakatan bersama.

Paper [10] menekankan mengenai bagaimana hendaknya seorang pemimpin bersikap dalam menghadapi dunia di masa yang akan datang. Selain itu [10] mengatakan bahwa pemimpin yang efektif tidak hanya sekedar mendelegasikan tugas, tetapi juga melakukan apa yang didelegasikan kepada para bawahannya. Lebih jauh Drucker juga mengingatkan bahwa percepatan akselerasi teknologi, kompetisi global, dan perubahan demografi telah menciptakan tipe organisasi baru yang tidak pernah dibayangkan sebelumnya.

a. Memberikan arahan dan makna pada usaha dan kerja yang dilakukan berdasarkan visi yang jelas.

b. Memiliki visi kepemimpinan secara realistis dan dapat meyakinkan serta menuntun organisasi mencapai cita-cita masa depan yang lebih baik. 
c. Mampu menganalisis permasalahan yang dihadapi organisasi dan mengetahui daya dukung yang dimilikinya.

d. Mampu menganalisis kekuatan dan kesempatan yang dimiliki organisasinya untuk mengantisipasi kelemahan- kelemahan serta ancaman-ancaman terhadap organisasi yang dipimpinnya.

e. Pemimpin yang dapat membangun, menciptakan dan mengkomunikasikan visi serta berfikir strategis untuk dapat mengarahkan dan merubah organisasi kearah yang lebih baik sehingga dapat meraih keunggulan dimasa depan[11].

Ciri-ciri utama kepemimpinan visioner adalah:

a. Berwawasan ke masa depan : pemimpin visoner mempunyai pandangan yang jelas terhadap suatu visi yang ingin di capai, agar organisasi yang dia masuki dapat berkembang. Sesuai dengan visi yang ingin dia capai.

b. Berani bertindak dalam meraih tujuan, penuh percaya diri, tidak peragu dan selalu siap menghadapi resiko. Pada saat yang bersamaan, pemimpin visioner juga menunjukkan perhitungan yang cermat, teliti dan akurat. Dalam memperhitungkan kejadian yang di anggapnya penting.

c. Mampu menggalang orang lain untuk kerja keras dan kerjasama dalam menggapai tujuan. Pemimpin visioner adalah sosok pemimpin yang patut di contoh, dia mau membuat contoh agar masyarakat sekitar mencontoh dia.

d. Mampu merumuskan visi yang jelas, inspirasional dan menggugah, mengelola 'mimpi' menjadi kenyataan: pemimpin visioner sangatlah orang yang mempunyai komitmen yang kuat terhadap visi di embannya, dia ingin mewujudkan visinya kedalam suatu organisasi yang dia masuki.

e. Mampu mengubah visi ke dalam aksi : dia dapat merumuskan visi kedalam misinya yang selanjutnya dapat diserap anggota organisasi. Yang dapat menjadikan bahan acuan dalam setiap melangkah kedepan.

f. Berpegang erat kepada nilai-niliai spiritual yang diykininya: pemimpin visioner sangatlah profesionalitas terhadap apa yang diyakini, seperti nilai- nilai luhur yang ada di bangsa ini. Dia sosok pemimpin yang bisa dijadikan tauladan.

g. Membangun hubungan (relationship) secara efektif: pemimpin visoner sangatlah pandai dalam membangun hubungan antar anggota, dalam hal memotivasi, memberi, membuat anggotanya lebih maju dan mandiri.

h. Innovative dan proaktif : dalam berfikir pemimpin vioner sangatlah kreatif dia mengubah berfiir konvesiomal menjadi paradigma baru, dia sangatlah sosok pemimpin yang kreatif dan aktif.

\subsection{Kinerja Guru}

Kinerja berasal dari kata "performance" dan sering diartikan dengan prestasi kerja atau ujuk kerja. Kinerja adalah suatu bentuk hasil kerja atau hasil usaha berupa tampilan fisik, maupun gagasan. Kinerja sering juga dihubungkan dengan kompetensi pada diri pelakunya.

Kinerja merupakan kegiatan yang dijalankan oleh tiap-tiap individu dalam kaitannya untuk mencapai tujuan yang sudah direncanakan. Berkaitan dengan hal tersebut terdapat beberapa definisi mengenai kinerja. Paper [12] menyatakan bahwa kinerja merupakan hasil atau keluaran dari suatu proses. Dikatakan lebih lanjut oleh [12] bahwa kinerja atau performance dapat diartikan sebagai prestasi kerja, pelaksanaan kerja, pencapaian kerja, hasil- hasil kerja atau unjuk kerja.

Kinerja adalah prestasi yang dapat dicapai oleh seseorang atau organisasi berdasarkan kriteria dan alat ukur tertentu, dimana alat ukur tersebut berupa efektivitas, efisiensi, dan produktivitas yang menurut Sustermeiser dikembangkan menjadi tiga puluh tiga variabel". Kinerja memiliki hubungan dengan produktivitas karena merupakan indikator dalam mencapai tingkat tingkat produktivitas yang tinggi dalam suatu organisasi.

Berkaitan dengan kinerja guru, wujud perilaku yang dimaksud adalah kegiatan guru dalam proses pembelajaran. Berkenaan dengan standar kinerja guru: "Standar kinerja guru itu berhubungan dengan kualitas guru dalam menjalankan tugasnya seperti: (1) bekerja dengan siswa secara individual, (2) persiapan dan perencanaan pembelajaran, (3) pendayagunaan mediapembelajaran, (4) melibatkan siswa dalam berbagai pengalaman belajar, dan (5) kepemimpinan yang aktif dari guru".

UU Republik Indonesia No. 20 Tahun 2003 tentang Sisdiknas pasal 39 ayat (2), menyatakan bahwa "pendidik merupakan tenaga profesional yang bertugas merencanakan dan melaksanakan proses pembelajaran, menilai hasil pembelajaran, melakukan pembimbingan dan pelatihan serta melakukan penelitian dan pengabdian kepada masyarakat, terutama bagi pendidik pada perguruan tinggi”. Keterangan lain menjelaskan dalam UU No. 14 Tahun 2005 Bab IV Pasal 20 (a) tentang Guru dan Dosen menyatakan bahwa standar prestasi kerja guru dalam melaksanakan tugas keprofesionalannya, guru berkewajiban merencanakan pembelajaran, melaksanakan 
proses pembelajaran yang bermutu serta menilai dan mengevaluasi hasil pembelajaran. Tugas pokok guru tersebut yang diwujudkan dalam kegiatan belajar mengajar merupakan bentuk kinerja guru.

Dari beberapa konsep pengertian kinerja guru menurut beberapa ahli, peneliti menyimpulkan yang dimaksud dengan kinerja guru adalah segala kemampuan yang ditunjukan guru dalam melaksanakan tugas mengajar pada kegiatan belajar mengajaw baik melakukan perencanaan, pelaksanaan dan mengevaluasi hasil belajar yang dilakukan secara menyeluruh sehingga menghasilkan perbaikan dan hasil kerja yang sangat memuaskan yang dapat dirasakan bagi siswa dan lingkungannya.

\subsection{Mutu dan Kualitas Sekolah}

Berbicara tentang mutu berbicara tentang sesuatu bisa barang atau jasa. Barang yang bermutu adalah barang yang sangat bernilai bagi seseorang, barang tersebut secara fisik sangat bagus, indah, elegan, mewah, antik, tidak ada cacatnya, kuat dan ukuran-ukuran lainnya yang biasanya berhubungan dengan kebaikan (goodness), keindahan (beauty), kebenaran (truth), dan idealitas. Hampir semua ingin memilikinya tetapi hanya sedikit saja yang dapat menjangkaunya.Jasa yang bermutu adalah pelayanan yang diberikan seorang atau organisasi yang sangat memuaskan, tidak ada keluhan bahkan orang tidak segan-segan untuk memuji dan memberi acungan jempol.

Mutu adalah suatu terminologi subjektif dan relatif yang dapat diartikan dengan berbagai cara dimana setiap definisi bisa didukung oleh argumentasi yang sama baiknya. Secara luas mutu dapat diartikan sebagai agregat karakteristik dari produk atau jasa yang memuaskan kebutuhan konsumen/pelanggan.Karakteristik mutu dapat diukur secara kuantitatif dan kualitatif. Dalam pendidikan, mutu adalah suatu keberhasilan proses belajar yang menyenangkan dan memberikan kenikmatan. Pelanggan bisa berupa mereka yang langsung menjadi penerima produk dan jasa tersebut atau mereka yang nantinya akan merasakan manfaat produk dan jasa tersebut.

Istilah mutu atau kualitas berasal dari bahasa Inggris yaitu quality. Dalam kamus Oxford kata quality yaitu the standard of something when it is compared to other things like it Yang artinya kualitas adalah suatu standar atau ukuran dari sesuatu ketika dibandingkan dengan hal lain yang sama. berikut:

Definisi mutu memiliki pengertian yang bervariasi, namun beberapa ahli telah mendefinisikan mutu seperti

a. Juran, mutu adalah kecocokan penggunaan produk ( fitness for use) untuk memenuhi kebutuhan dan kepuasan pelanggan.

b. Crosby, mutu adalah conformance to requirement, yaitu sesuai dengan yang diisyaratkan atau distandarkan.

c. Deming, mutu adalah kesesuaian dengan kebutuhan pasar atau konsumen.

d. Feigenbaum, mutu adalah kepuasan pelanggan sepenuhnya ( full customer satisfaction)

e. Goestch dan davis mutu merupakan suatu kondisi dinamis yang berhubungan dengan produk, jasa, manusia, proses, dan lingkungan yang memenuhi atau melebihi harapan.

f. Ishikawa mengatakan bahwa " quality is customer satisfaction". Dengan demikian pengertian mutu adalah keadaan yang sesuai dan melebihi harapan pelanggan hingga memperoleh kepuasan.

Dari definisi beberapa ahli tersebut dapat diambil kesimpulan bahwa mutu adalah keadaan yang sesuai dan melebihi harapan pelanggan memperoleh kepuasaan. Mutu adalah kemampuan (ability) yang dimiliki oleh suatu produk atau jasa (service)yang dapat memenuhikebutuhan atau harapan, kepuasan (satisfaction) pada pelanggan (customers) Dalam konteks pendidikan, pengertian mutu mengacu pada masukan, proses, luaran, dan dampaknya.Mutu masukan dapat dilihat dari beberapa sisi.Pertama, kondisi baik atau tidaknya masukan sumber daya manusia seperti kepala sekolah, guru laboran, staf tata usaha, dan siswa. Kedua, memenuhi atau tidaknya kriteria masukan material berupa alat peraga, buku-buku, kurikulum, prasarana, sarana sekolah, dan lainlain.Ketiga, memenuhi atau tidaknya kriteria masukan yang berupa perangkat lunak, seperti peraturan, struktur organisasi, dan deskripsi kerja.Keempat, mutu masukan yang bersifat harapan dan kebutuhan, seperti visi, motivasi, ketekunan, dan cita-cita. Hasil pendidikan dipandang bermutu jika mampu melahirkan keunggulan akademik dan ekstrakulikuler pada pesrta didik yang dinyatakan lulus untuk satu jenjang pendidikan atau menyelsaikan program pembelajaran tertentu.

Mutu dibidang pendidikan meliputi mutu input, proses, output, dan outcome. Input pendidikan dinyatakan bermutu jika siap berproses. Proses pendidikan bermutu apabila mampu menciptakan suasana yang PAKEMB (Pembelajaran yang Aktif, Kreatif, Menyenangkan, dan Bermakna). Output, dinyatakan bermutu jika hasil belajar akademik dan non akademik siswa tinggi. Outcome, dinyatakan bermutu apabila lulusan cepat terserap di dunia kerja, gaji wajar, semua pihak mengakui kehebatan lulusan dan merasa puas.

Mutu pendidikan menurut Permendiknas nomor 63 tahun 2009 adalah tingkat kecerdasan kehidupan bangsa yang dapat diraih dari penerapan Sistem Pendidikan Nasional. Merujuk pada pendapat Deming yang 
mendefinisikan mutu merupakan kesesuaian kebutuhan dengan pasar atau konsumen. Masyarakat dan orangtua siswa membutuhkan sekolah yang mempunyai kurikulum yang menyeimbangkan antara pendidikan agamis dan akademik agar anaknya mampu menjawab tantangan zaman yang semakin beragam.

\section{HASIL DAN PEMBAHASAN}

\subsection{Strategi Pemecahan Masalah}

SD Negeri Soko merupakan salah satu lembaga pendidikan yang terletak di Desa Soko, Kecamatan Glagah, Kabupaten Lamongan. Menjadi kepala sekolah di SD Negeri Soko harus mempunyai kemampuan dalam merumuskan visi serta mengelola organisasi secara baik. Gaya kepemimpinan di SD Negeri Soko yang tepat yaitu : (1) Memiliki wawasan ke masa depan.; (2) Berani, percaya diri, dan siap menghadapi resiko; (3) Mampu mengajak orang lain untuk bekerjasama dalam mencapai visi; (4) Mampu merumuskan visi yang jelas dan inspirational; (5) mampu mengubah visi menjadi aksi; (6) Menjalin hubungan secara efektif; serta (7) Innovative dan proactive[13].

Peran sebagai kepala sekolah adalah perencana, pengatur, pemimpin dan pengontrol semua kegiatan belajar mengajar dan kegiatan yang berhubungan dengan SD Negeri Soko. Selain peran tersebut kepala sekolah juga mempunyai peran sebagai menajer, fasilitator, motivator, administrator, dan supervisor.

Sistem menejemen yang diimplementasikan adalah Manajemen Berbasis Sekolah (MBS) yang mengakomodir melalui analisa kebutuhan peserta didik dan walinya serta kepuasan layanan pendidikan yang diberikan menjadi salah satu tolak ukur kualitas layanan pendidikan, SD Negeri Soko mempunyai visi "Terciptanya manusia yang beriman dan taqwa, cerdas, terampil, dan berbudi pekerti luhur " setiap lembaga pendidikan pasti memiliki tujuan menjadikan peserta didik cerdas, ukuran kecerdasan anak yang satu berbeda dengan anak yang lain, di sekolahan ini yang dimaksud dengan cerdas adalah cerdas dalam ilmu pengetahuan (IPTEK), iman dan taqwa (IMTAQ) dan budi pekerti yang luhur.

Visi lembaga, di klasifikasikan menjadi tiga, jangka pendek, langkah jangka menengah dan jangka panjang, untuk itu dibutuhkan pemipin visioner yang mempunyai integritas, kompetensi, konsistensi, juga menstimulasi dan motivasi tenaga pendidik dan tenaga kependidikan SD Negeri Soko untuk berinovasi dan berkreasi dalam pembelajaran, baik di dalam kelas maupun di luar kelas. Mengakomodir ego untuk merealisasikan visi organisasi, memiliki perhatian kepada tim dan mempunyai penilaian kerja yang adil serta mempunyai human skill dalam memecahkan permasalahan.

Strategi implementasi gaya kepemimpinan visioner di SD Negeri Soko adalah strategi tindakan kepemimpian visioner antara lain:

1. Fokus Pada Tujuan Organisasi.

Keseluruhan perilaku dan pengambilan keputusan dalam sebuah organisasi difokuskan pada tujuan akhir organisasi. Hal-hal yang membuat ketidakefektifan program diminimalisir supaya semua tindakan organisasi dapat mengarah pada tujuan. di SD Negeri Soko sudah memfokuskan semua kegiatan pembelajaran baik di dalam kelas maupun di luar kelas sesuai dengan tujuan organisasi.

2. Membuat Rencana Jangka Panjang.

Hal ini penting untuk dilakukan supaya langkah-langkah program selama 5-10 tahun dapat terukur. Mendesain program, menentukan pemimpin dan penangungjawab program juga harus dilakukan supaya pencapaian tujuan jangka panjang dapat berjalan maksimal. Hal yang harus dilakukan oleh pemimpin visioner adalah melakukan rekruitmen, seleksi, orientasi, pelatihan, performance assessment dan penetapan tugas dan tanggungjawab masing-masing.

3. Mengembangkan Visi Bagi Masa Depan Organisasi.

Strategi ini adalah membangun paradigma baru dimulai dengan menjawab pertanyaan: apabila kita menginginkan dan bermimpi akan seperti dan menjadi apa organisasi kita kelak di kemudian hari? Setelah visi tersusun, maka idealnya visi tersebut harus menjadi inspirasi dan terinternalisasi bagi seluruh aktivitas organisasi, baik dalam rapat-rapat, dalam perbincangan, dan dalam menghadapi segala tantangan dan peluang yang ada. Di SD Negeri Soko visi sudah dikembangkan dan di internalisasi dalam kehidupan sehari-hari.

4. Selalu Berada Dalam Kondisi Siap Dan Dinamis Untuk Perubahan.

Pemimpin visioner akan selalu siap menangkap informasi-informasi mutakhir mengenai perubahan perubahan organisasi yang mungkin akan berdampak kepada organisasi 3-5 tahun ke depan. Strategi ini juga berupa dorongan dan fasilitasi kepada anggota organisasi untuk peka dan memiliki rasa kaingin-tahuan yang tinggi dalam segala hal yang terkait dengan kejadian-kejadian dan berita yang relevan dengan tuntutan perubahan. Dalam hal ini SD Negeri Soko mengubah total mindset berawal tenaga pendidik dan kepemimpinan mempunyai mindset konvensional yang pasif dan yang penting jalan, kemudian diubah menjadi mindset yang progresif dan aktif. 
5. Selalu Mengetahui Perubahan Kebutuhan Konstituen.

Keinginan dan kebutuhan pelanggan seringkali mengalami perubahan. Oleh karena itu, sebaiknya organisasi menyediakan informasi-informasi yang up to date yang terkait dengan hal ini. Tindakan melakukan komunikasi langsung dengan wali murid, mengefektifkan layanan kotak kritik dan saran, adalah beberapa cara yang dapat dilakukan agar organisasi selalu mengetahui harapan dan keinginan wali murid dan masyarakat. Kepala sekolah juga membuka secara lebar pintu komunikasi baik melalui tatap muka maupun melalui telefon. Dengan demikian organisasi akan selalu siap untuk melaksanakan perubahan dan perbaikan dalam rangka konsistensi terhadap kepuasan pelanggan.

Selain strategi di atas kepala sekolah SD Negeri Soko juga melaksanakan perencanaan yang matang (planning), menerapkan program (implementating) dan melakukan control dan evaluasi (evaluating). Faktor pendukung meningkatnya mutu dan kualitas sekolah juga tidak lepas dari kinerja guru SD Negeri Soko. Karena salah satu penentu keberhasilan pendidikan ditentukan oleh kinerja seorang tenaga pendidik atau biasa disebut dengan guru. Peran guru sangat diperlukan dalam membentuk peserta didik menjadi manusia yang berkualitas.

Kinerja mengajar guru merupakan komponen penting dalam penciptaan efektivitas sekolah. salah satu unsur yang paling berperan dalam meningkatkan kinerja mengajar guru adalah kepla sekolah, dalam hal ini kepala sekolah yang menjalankan model kepemimpinanan visioner, karena kepemimpinan visioner dalam aktivitasnya sebagai penentu arah, melihat kedepan bagaimana mengelola sekolah dan sumber daya yang ada di sekolah demi tercapainya visi dan misi sekolah tersebut.

\subsection{Hasil yang Diperoleh}

Kepemimpinan visioner kepala sekolah dalam konteks best practice ini adalah menekankan pada sikap pemimpin yang mampu melihat situasi yang akan terjadi di masa mendatang, ia membuat kebijakan sesuai dengan kebutuhan masyarakat atau konsumen, mampu memecahkan masalah yang meliputi peluang, hambatan dan tantangannya, bervisi baik dan mampu mengkomunikasikannya. Ia berani mengambil resiko untuk membuat perubahan yang besar pada kinerja guru. Dalam best practice ini kepemimpinan visioner kepala sekolah memiliki sub variabel meliputi: Fokus pada tujuan organisasi; Membuat rencana jangka panjang; Mengembangkan Visi Bagi Masa Depan Organisasi; Selalu Berada Dalam Kondisi Siap Dan Dinamis Untuk Perubahan; dan Selalu Mengetahui Perubahan Kebutuhan Konstituen.

Hasil best practice menunjukkan bahwa fokus pada tujuan organisasi memiliki pengaruh signifikan terhadap mutu dan kualitas SD Negeri Soko. Hal ini didukung dengan hasil persepsi responden yang menilai penting keberadaan unsur-unsur kepemimpinan visioner kepala sekolah yang terdiri dari Fokus pada tujuan organisasi; Membuat rencana jangka panjang; Mengembangkan Visi Bagi Masa Depan Organisasi; Selalu Berada Dalam Kondisi Siap Dan Dinamis Untuk Perubahan; dan Selalu Mengetahui Perubahan Kebutuhan Konstituen. Sehingga dalam best practice ini, ditemukan pengaruh positif dan signifikan kemampuan dalam menentukan arah organisasi, memahami keinginan masyarakat atau konsumen, berpengaruh, dan mampu mengantisipasi masa depan/menjadi agen perubahan secara simultan dan parsial terhadap kinerja guru di SD Negeri Soko.

Temuan adanya pengaruh kepemimpinan visioner kepala serta kinerja guru di SD Negeri Soko, sebagai bukti nyata adanya pengaruh kepemimpinan visioner kepala sekolah terhadap kinerja guru SD Negeri Soko sehingga dengan meningkatnya kinerja guru dapat pula meningkatkan mutu dan kualitas SD Negeri Soko. Kepala sekolah mempunyai kemampuan dalam menggerakkan, mempengaruhi serta mengayomi seluruh bawahannya serta dapat mendayagunakan secara maksimal seluruh potensi sumber daya yang dimiliki sekolah dalam mencapai tujuan di dalam kepemimpinnya sesuai dengan visi, misi dan tujuan pendidikan yang ada di SD Negeri Soko. Hal menggambarkan bahwa Kepala Sekolah SD Negeri Soko dalam kepemimpinannya memahami visi sekolah dan memiliki visi kerja yang jelas, mampu dan mau bekerja keras dalam memimpin sekolah, tekun dan tabah dalam bekerja dengan bawahan, memberikan layanan optimal dengan tetap terampil dan rendah hati serta memiliki disiplin kerja yang kuat.

Kepemimpinan Kepala Sekolah SD Negeri Soko yang visioner perlu mendapat perhatian secara serius dan dukungan penuh dari para bawahannya karena sangat mempengaruhi kesuksesan dari kebijakankebijakan keputusan yang diambil dalam penentuan arah sekolah yang akan dicapai, dimana salah satu fungsi kepala sekolah adalah memiliki visi yang visioner. Salah satu fungsi utama pemimpin adalah sebagai supervisor, yaitu membina, melatih, mendidik, mengawasi, menilai, dan memberikan contoh kerja terbaik bagi seluruh anggota organisasi yang dipimpinnya.

Tanggungjawab Kepala Sekolah SD Negeri Soko sebagai seorang pemimipin yang visioner sangatlah rumit dan berat karena berkaitan dengan pengelolaan sumberdaya dan sumber daya material (sarana dan prasarana) pendidikan yang ada di sekolah. Oleh sebab itu, ketrampilan dalam memimpin sangat dibutuhkan, Kepala 
Sekolah SD Negeri Soko yang visioner harus mampu memotivasi para guru untuk meningkatkan profesionalismenya dalam melaksanakan tugas dan fungsinnya untuk mencapai tujuan sesuai dengan visi, misi dan sasaran yang akan dicapai sekolah. Hal ini sejalan dengan pendapat yang dikemukakan oleh [3] yang mengungkapkan bahwa: "Pemimpin pendidikan harus bertanggungjawab menciptakan kultur organisasional yang dapat meningkatkan pertumbuhan dan perkembangan partisipasi seluruh pihak yang terlibat dalam pengajaran dan pembelajaran".

Kepala Sekolah SD Negeri Soko sebagai pemimpin yang visioner bisa bekerjasama, berkomunikasi dan memahami individu para bawahannya di sekolah yang dipimpin dengan maksud meningkatkan motivasi para guru maupun para staf dalam mencapai tujuan. Hal ini sejalan dengan pendapat yang dikemukakan oleh [14] yang menyatakan bahwa untuk memotivasi para guru maupun para staf, Kepala Sekolah sebagai pemimpin harus melakukan hal-hal sebagai berikut: (1) Menjalin hubungan dengan guru; (2) Menjalin komunikasi dengan guru; (3) Memberikan bimbingan dan bantuan dalam menyelesaikan tugas guru; (4) Membangun semangat/moral kerja guru; (5) Memberikan penghargaan kepada guru yang berprestasi; (6) Menyelesaikan segala permasalahan di sekolah; (7) Mengikut sertakan guru dalam merumuskan pengambilan keputusan; (8) Menyelsaikan konflik di sekolah; (9) Menghormati peraturan sekolah; dan (10) Menciptakan iklim kompetitif yang sehat diantara guru.

Kepala sekolah SD Negeri Soko dalam kepemimpinannya yang visioner mampu mengantisipasi segala kejadian yang mungkin timbul di sekolah yang dipimpinnya, mampu mengelola masa depan dan mendorong bawahan utuk berbuat dengan cara-cara yang tepat. Hal ini menunjukkan kepemimpinan Kepala Seorang SD Negeri Soko yang visioner mampu melihat tantangan dan peluang di sekolah yang dipimpin sebelum keduanya terjadi, selain itu mampu memposisikan sekolah yang dipimpin mencapai tujuan-tujuan terbaiknya.

Kemampuan Kepala Sekolah SD Negeri Soko sebagai seorang pemimpin yang visioner menggambarkan dengan jelas tujuan-tujuan yang akan diraihnya di masa depan adalah syarat utama bagi kesuksesannya dalam mempimpin seluruh sumber daya yang ada di sekolah yang dipimpinnya. Paper [3] menyebutkan bahwa kepemimpinan yang efektif dimulai dengan visi yang jelas.Visi yang akan menjadi daya atau kekuatan untuk melakukan perubahan, mendorong terjadinya proses ledakan kreatifitas yang dahsyat melalui integrasi maupun sinergi berbagai keahlian dari orang-orang yang ada dalam organisasi tersebut.

Kepemimpinan visioner kepala sekolah berpengaruh secara positif dan signifikan terhadap efektivitas sekolah pada Sekolah Dasar Negeri Hal ini mengindikasikan efektivitas sekolah salah satunya ditentukan oleh kepemimpinan visioner kepala sekolah. Dengan demikian, semakin baik kepemimpinan visioner kepala sekolah maka efektivitas sekolah akan semankin meningkat.

Kinerja mengajar guru berpengaruh secara positif dan signifikan terhadap efektivitas sekolah pada Sekolah Dasar Negeri. Hal ini mengindikasikan efektivitas sekolah salah satunya ditentutukan oleh kinerja mengajar guru. Dengan demikian, semakin baik kinerja mengajar guru maka efektivitas sekolah akan semakin baik.

Kepemimpinan visioner kepala sekolah dan kinerja mengajar guru berpengaruh secara positif dan signifikan terhadap efektivitas sekolah pada Sekolah Dasar Negeri. Hal ini mengindikasikan efektivitas sekolah ditentukan oleh kepemimpinan visioner kepala sekolah dan kinerja mengajar guru secara bersama-sama. Dengan demikian, semakin baik kepemimpinan visioner kepala sekolah dan kinerja mengajar guru maka efektivitas sekolah akan semakin baik dan mengalami peningkatanPada bagian ini dapat diuraikan mengenai hasil dari penelitian beserta pengujian yang telah dilakukan. Selain itu, disampaikan juga mengenai pembahasan dari penelitian maupun pengujian yang telah dilakukan.

\section{KESIMPULAN DAN REKOMENDASI}

\subsection{Kesimpulan}

Simpulan dari best practice yang dapat penulis kemukakan adalah Kepemimpinan visioner Kepala Sekolah SD Negeri Soko dalam upaya meningkatkan mutu dan kualitas SD Negeri Soko dapat dikategorikan kategori tinggi. Selain itu, kinerja guru SD Negeri Soko dalam merencanakan proses pembelajaran, dan mengevaluasi hasil pembelajaran sangat baik. Mutu dan Kualitas Sekolah dapat diwujudkan dengan kepemimpinan pendidikan yang kuat, ekspektasi guru dan staf yang tinggi, adanya kemitraan sekolah dan masyarakat, adanya iklim yang positif dan kondusif, kemajuan siswa sering dimonitor, serta menekankan pada keberhasilan siswa. Kepemimpinan visioner kepala sekolah berpengaruh positif dan signifikan terhadap mutu dan kualitas SD Negeri Soko. Selain itu, Kinerja guru berpengaruh positif dan signifikan terhadap mutu dan kualitas SD Negeri Soko.

\subsection{Rekomendasi}

Adapun yang menjadi rekomendasi penelitian ini yang bermanfaat bagi kemajuan Sekolah Dasar Negeri, diantaranya adalah kepala sekolah harus terus berupaya meningkatkan profesionalitas kepemimpinan dengan mengikuti pelatihan yang diselenggarakan oleh Dinas ataupun Lembaga-lembaga non pemerintahan. Selain itu, 
Kinerja mengajar guru perlu selalu di-upgrade. Oleh karena itu perlu dilakukan peningkatan kemampuanan kompetensi professional guru terutama kemampuan dalam menyusun dan memilih jenis evaluasi pembelajaran, melakukan evaluasi pembelajaran, melakukan pengadministrasian nilai PBM, merancang dan melaksanakan program remedial. Peningkatkan kompetensi ini dilakukan dengan memberikan pelatihan kepada guru pada akhir semester guna merencanakan program semester yang akan datang yang diselenggarakan oleh sekolah/dinas.

\section{DAFTAR PUSTAKA}

[1] L. R. Beach, "Leadership and the art of change: A practical guide to organizational transformation," Sage, 2006.

[2] A. Baedowi, "Manajemen Sekolah Efektif: Pengalaman Sekolah Sukma Bangsa," Pustaka Alvabet, 2015.

[3] A. Beddu, "Pengaruh Kepemimpinan Visioner Kepala Sekolah Terhadap Kinerja Guru SMP Negeri 12 Sigi," Katalogis, vol. 4, no. 7, 2002.

[4] B. Nanus, "Kepemimpinan Visioner; Menciptakan Kesadaran akan arah dan Tujuan di Dalam Organisasi. Alih Bahasa: Frederik Ruma," Jakarta: Prenhallindo, 2011.

[5] A. Komariah dan C. Triatna, "Visionary Leadership Menuju Sekolah Efektif," Jakarta: Bumi Aksara, 2016.

[6] A. Masruri, "Strategi Kepala Sekolah Dalam Meningkatkan Mutu Pendidikan Islam (Studi Kasus Di MAS Jam'iyyah Islamiyyah Pondok Aren)," Mumtaz: Jurnal Studi Al-Quran dan Keislaman, vol. 3, no. 1, pp. 96-112, 2019.

[7] E. Karweti, "Pengaruh kemampuan manajerial kepala sekolah dan faktor yang mempengaruhi motivasi kerja terhadap kinerja guru SLB di Kabupaten Subang," Jurnal penelitian pendidikan, vol. 11, no. 2, pp. 77-89, 2010.

[8] U. W. S. Adinata, "Pengaruh kepemimpinan transformasional, motivasi, dan budaya organisasi terhadap kinerja karyawan kjks bmt tamzis bandung," Jurnal Ekonomi, Bisnis \& Entrepreneurship, vol. 9, no. 2, pp. 136-157, 2016.

[9] L. Isnaini, "STRATEGI KEPEMIMPINAN ABAD 21: VISIONER, KREATIF, INOVATIF, DAN CERDAS EMOSI," PRODU: Prokurasi Edukasi Jurnal Manajemen Pendidikan Islam, vol. 1, no. 2, 2020.

[10] H. Syamsul, "Penerapan Kepemimpinan Kepala Sekolah dalam Meningkatkan Kinerja Guru pada Jenjang Sekolah Menengah Pertama (SMP)," Idaarah: Jurnal Manajemen Pendidikan, vol. 1, no. 2, 2017.

[11] A. Irwana, "Kepemimpinan visioner kepala sekolah dan kinerja guru terhadap efektivitas sekolah di sekolah dasar," Jurnal Administrasi Pendidikan, vol. 22, no. 2, 2015.

[12] N. Nursam, "Manajemen Kinerja," Kelola: Journal of Islamic Education Management, vol. 2, no. 2, 2017.

[13] N. Usman, "Manajemen Peningkatan Mutu Kinerja Guru: Konsep, Teori, dan Model," Bandung: Citapustaka Media Perintis, 2012.

[14] A. Zakso \& U. Radiana, "Pelaksanaan supervisi akademik pengawas sekolah sebagai upaya peningkatan profesionalisme guru SMP Negeri 1 Bengkayang," Jurnal Pendidikan dan Pembelajaran Khatulistiwa, vol. 2, no. 3, 2013. 